\title{
PRESERVATION AND CONSERVATION OF OLD ADMINISTRATIVE RECORDS IN ETCHE LOCAL GOVERNMENT AREA OF RIVERS STATE
}

\author{
Anthonia Omehia $^{1}$ and Anele Emmanuel ${ }^{2}$ \\ ${ }^{1}$ Department of Library and Information Science, Ignatius Ajuru University of Education. \\ Rumuolumeni, Port Harcourt, Nigeria. Email: aomehia@ gmail.com \\ ${ }^{2}$ Department of Library and Information Science, Ignatius Ajuru University of Education. \\ Rumuolumeni, Port Harcourt, Nigeria. Email: aneleemmanuel@gmail.com
}

Cite this article:

Anthonia O., Anele E. (2021), Preservation and

Conservation of Old Administrative Records in Etche Local Government Area of Rivers State. British Journal of Library and Information Management 1(1), 16-24. DOI: 10.52589/BJLIMMIFXR1AL.

\section{Manuscript History}

Received: 8 May 2021

Accepted: 28 May 2021

Published: 22 June 2021

Copyright $\odot 2020$ The Author(s). This is an Open Access article distributed under the terms of Creative Commons Attribution-NonCommercialNoDerivatives 4.0 International (CC BY-NC-ND 4.0), which permits anyone to share, use, reproduce and redistribute in any medium, provided the original author and source are credited.
ABSTRACT: The study examined the preservation and conservation of old administrative records in the Etche Local Government Area of Rivers State. Three objectives were examined for the study namely: the techniques used in preservation and conservation of old administrative records, the causes of deterioration of these old administrative records in Etche, and the challenges. The descriptive survey research was adopted on a total of (28) employees and management of Etche Local Government Area. A total of 18 employees and 10 management staff were used. The study found among other things that the effect of rodents, fire, floods, dampness, moisture, etc. were the major causes of deterioration of old administrative records. Identified challenges were lack of record offices, lack of policy strategy, staff and funds. Based on the findings, a number of recommendations were made, which include: employment of professional staff, training and retraining of staff, good funding and policy statement in the area of disaster preparedness, so as to reduce loss or damage of old administrative records.

KEYWORDS: Preservation, Conservation, Old Administration Records, Print Information, Print Resources. 


\section{INTRODUCTION}

In the past few decades, library information has made a quantum leap due to technology-driven application, which marked the most significant breakthrough in record keeping. It is instructive to note that in the past few decades, record keeping was done manually since electronic data processing was not in vogue. Thus, the information resources and information service delivery of administrative records have been revolutionized by electronics into digital formats, since print resources are no longer sufficient to cope with the ever-increasing information demand. Nwosu et al. (2013) opined that the advent of information and communication technology (ICT) has shifted the focus of local government administrative records to electronic information, even though the printed medium, which forms the bedrock of libraries, are still provided.

However, irrespective of the type of records, library materials are a good source of information and as such, they are made to be used, read and studied. This requires that library materials be accessible to users, thus subjecting them to handling. Any form of use will exacerbate deterioration of the item and ultimately its destruction, if intervention does not occur (Rosenberg, 1995 cited in Shameenda, 2011). According to the National Library of Australia (2004), one of the major crises facing libraries throughout the world is the rate of deterioration of their collections. Since records are composed mainly of organic materials, they are subject to natural deterioration. Most of these old administrative records of the Etche L.G.A. are based on paper either in book or sheet form, bound volumes, newspaper, serials, manuscripts, maps, water colours, prints and drawings. The collections of modern materials such as sound tapes and electronically stored information such as CD ROMs and computer discs are growing rapidly; most records collections are essentially temporary.

Conservation and preservation of deteriorating information resources are a global concern and must be aggressively responded to by record managers if their mission of providing information of their patrons would be realized (Akande, 2009).

Srivastava and Kimar (1986), cited in Sawant (2014), see conservation and presentation as two words that have different implications, though they are coterminous. Preservation by definition involves activities associated with maintaining library and archival materials for use, either in their original physical form or in some other usable way, while conservation is an aspect of preservation activity that implies the active use of preventive measures or processes to repair damaged materials and ensure the continued existence of the materials. Conservation and preservation are the processes of keeping or maintaining an object safe from harm, loss, damage or destruction, and keeping it in a reasonable sound condition for present and future use. Preservation deals with the regular or continuous maintenance aspect whereas conservation deals with the curative treatment (Sawant, 2014).

The term conservation was defined in the International Records Management Trust (1999) as the intrusive protection of archival materials by the minimal physical and chemical treatments necessary to resist further deterioration, which will not adversely affect the integrity of the original. It was further explained that it is a specific work to protect materials and improve the environment in which they are kept. Conservation is preservation at the item level. It embraces those activities that improve the condition of the physical object or protect it from damage (Jordan, 2003). 
In the IFLA principles of care and handling of library materials (2010), conservation was defined as specific practices taken to slow down deterioration and prolong the lifespan of an object by direct intervening in its physical or chemical make-up. The composition of some of the media of storing information makes deterioration unavoidable. Deterioration may set in through the natural aging process or as a result of other factors such as chemical composition of the media of information, biological agents, environmental factors, physical agents and improper handling. It is therefore imperative to take certain conservation measures geared towards slowing down deterioration to prevent losing these vital records. Conservation involves taking protective measures to prevent decay and consequently, the loss of vital resources.

The IFLA principles for the care and handling of materials (2010), also defined preservation to include all the managerial and financial considerations including storage and accommodation provision, staffing levels, policies, techniques, and methods involved in preserving library and archival materials and the information contained in them. While conservation is a direct physical intervention arresting or slowing down deterioration of library materials, preservation involves both the direct and indirect actions. In preservation, consideration is given to every element that promotes the protection of the materials, including housing, storage system and security against such threats as theft, mutilation and poor handling. Preservation is therefore a broader concept and it includes conservation.

\section{Statement of Problem}

It has been observed that local governments, which are the tiers of government, pay little or no attention to the issue of preservation and conservation of old administrative records, in spite of the huge allocation that accrue to them. This observation is seen in the manner in which records are kept and sometimes lost. This lacuna has become endemic amongst local government councils in Nigeria. The fact that they do not have a functional library in the council speaks volume of this assertion.

Against this backdrop therefore, we want to examine if the council under study has a preservation and conservation policy in terms of how old administration records are preserved and conserved. We also want to determine if the L.G.A. has some trained staff that can manage these records to avoid deterioration.

\section{Objectives of the study}

The general objective of this study is to examine the preservation and conservation of old administrative records in Etche Local Government Council of Rivers State. The specific objectives are as follows:

1. To identify the techniques used in preservation and conservation of old administration records in Etche Local Government Area.

2. To examine the causes of deterioration of print information in Etche Local Government Area of Rivers State.

3. To determine the challenge facing preservation and conservation practices of print resources in Etche Local Government Area of Rivers State. 


\section{Research Questions}

Based on the objectives of this study, the following research questions sufficed:

1. What are the techniques used in preservation and conservation of electronics in print information resources?

2. What are the causes of deterioration of print and electronic information resources in Etche Local Government Area?

3. What are the challenges of preservation and conservation practices of print and electronic information resources in Etche Local Government Area?

\section{CONCEPTUAL REVIEW}

\section{Techniques for Preservation and Conservation of Print and Electronic Information Resources}

Since the way and manner EIRs deteriorate differ from those of other print resources in the library, so also do the techniques and strategies for its preservation and conservation differ. Some of these techniques as identified by Sawant (2014) include: backup, refreshing, emulation, migration, conversion to paper format, preservation metadata and encapsulation. Backup, as a procedure, involves copying and storing contents in multiple locations to create availability and ready replacement of information in the case of failure or other catastrophes of EIRs to new storage media. It is a short term preservation technique for copying information to new media before the old media becomes unreadable. Emulation is a strategy for long term preservation of EIRs; here, old media are mimicked into new media environments. The digital archive will be able to pick the resources itself. It is essentially a way of preserving the functionality of an access to digital information, which might otherwise be lost due to technology obsolescence. Migration is a set of organized tasks designed to achieve periodic transfer of digital materials from one hardware/software configuration to another or from one generation of computer technology to a subsequent generation (Sawant, 2006).

EIRs can also be converted to paper format through printing, photocopying and scanning, and the hard copy would be kept. This approach is however hinted at as digital objects become more complex and could contain features that can only be preserved in digital formats. Preservation of metadata is another technique; it is highly useful for long-term preservation of EIRs. Metadata is data associated with objects which relieves the potential user of having to have full knowledge of their characteristics (Sawant, 2006).

Another preservation strategy is encapsulation, which involves the grouping together of resources and whatever is necessary to maintain access to it. In contrast to the migration approach, the encapsulation approach retains the record in its original form, but encapsulates it with a set of instructions on how the original should be interpreted. Encapsulation is considered a key element of emulation (Iyishu \& Nkanu, 2013).

Many users handling electronic information resources (EIR) mishandle them, in terms of touching the reels of CDs, not putting them in their packs and shelves appropriately, among 
others. Hence, the users of electronic information resources should be properly guided to avoid loss or deterioration of valuable resources.

Natural disasters caused by earthquakes, fire, flood or water, are also causes of loss and deterioration of electronic and print information resources (Iyishu, 2013). Evans (1995) also explained that non-print materials are particularly sensitive to the effects of ultraviolet light, so videotapes and micro forms should never be shelved near a window.

\section{Challenges Facing the Preservation and Conservation of Records}

Myriads of scholars like Wamukoga and Mutula (2005) and the National Library of Australia (2003), among others in Iyishu and Nkanu (2013) cited the following challenges to the preservation of digital materials viz:

1. Continuous migration: Another challenge of digital preservation, which arises from the challenge of rapid technological obsolescence, is the need for continuous migration. Migration is a means of overcoming technological obsolescence by transferring digital resources from one hardware/software generation to the next. Rosenberg (1999) sees continuous migration as an organized task designed to achieve periodic transfer of digital material from one hardware/software configuration to another or from one generation of computer technology to a subsequent generation. Migration then becomes a challenge in preservation and conservation of EIRs because the migration version of a document is never the same as the original resource.

2. Lack of awareness about digital migration preservation: The UNESCO draft charter on the preservation of digital heritage (National Library of Australia, 2003) stressed the need for urgent awareness, raising an advocacy in favour of preservation of digital materials. It proposed the altering of policy makers and sensitizing the public to both the potential of the digital media and the practicalities of digital preservation.

3. Lack of legislation, policy and strategy: According to the National Library of Australia (2003), as cited by Iyishu and Nkanu (2013), lack of legislation is a major challenge of preservation of digital materials. They stressed further that internal links bring additional challenges in terms of copyright of software required to access digital files, and the right to copy for preservation has not been adequately articulated in most national legislations. Furthermore, Wamukoya and Mutula (2005) in Oluwaniyi (2015) said that most African countries including Nigeria do not have a National Information Policy (NIP), which makes the formulation of preservation policies in libraries and information centers difficult.

4. Lack of collaboration and partnership: Another major obstacle of digital preservation is lack of collaboration and partnership among stakeholders, as well as ack of clearly assigned responsibilities and resources for the long term preservation of digital materials (Wamukoya \& Mutula, 2005). The UNESCO draft charter on the preservation of digital heritage (National Library of Australia, 2003) also stressed the need for collaboration and partnership on the part of governments, creators, publishers, relevant industries and heritage institutions. According to her, in the face of the current digital divide, it is necessary to reinforce international cooperation and solidarity to help all countries to enable creation, dissemination, preservation and continued accessibility of their digital heritage. Industries, publishers and mass communication media are urged to promote and share knowledge and technical expertise. 
5. Deterioration and loss of EIRs: There is the possibility of digital media getting lost in the event of disasters such as fire, flood, equipment failure, or viral attack and system crash.

6. Absence of policy on disaster planning: The impact of the absence of disaster planning and mitigation measures result in unnecessary and sometimes, permanent loss of valuable information resources.

7. Poor maintenance culture: Poor maintenance culture, as pointed out by Popoola (2003), is a major challenge facing African countries generally. The management of libraries and archives in Africa has poor maintenance culture of infrastructural facilities such as telephones, electricity, water supply, laboratory equipment, buildings, disaster control devices, computers, etc. meant for their preservation and conservation operations.

8. Lack of training and retraining on preservation of EIRs: Ajidahun (2007) in Oluwaniyi (2015) said that there were professional librarians in the university libraries in Nigeria whose knowledge of library automation had been rendered obsolete owing to lack of training and retraining courses; development poses challenges to their coping with modern library practices.

\section{Methodology}

This study adopted a descriptive survey design, which allowed the researcher to collect data from respondents, using a structured questionnaire. A random sampling technique was needed to select twenty-five (25) employees from Etch Local Government, twenty (20) employees, and five (5) from management.

\section{RESULTS}

Data Administered and Retrieval Rate

\begin{tabular}{lllll}
\hline Respondents & No Distributed & No retrieved & $\begin{array}{c}\text { No } \\
\text { unretrieved }\end{array}$ & \% retrieved \\
\hline Employees & 20 & 18 & 2 & 64.28 \\
Management & 10 & 10 & - & 35.71 \\
Total & $\mathbf{3 0}$ & $\mathbf{2 8}$ & $\mathbf{2}$ & $\mathbf{9 9 . 9 9}$ \\
\hline
\end{tabular}

Source: Survey data 2019

From table 1 above, a total of thirty (30) respondents were surveyed, and a total of twenty-eight completed their questionnaires. Eighteen (18) employees, which represent $64.28 \%$, completed and returned their questionnaires, while ten (10), which represent $35.71 \%$ of the management staff, completed and returned their questionnaires. 
Research Question One: The techniques used in preservation and conservation of electronic and print information resources.

\begin{tabular}{lcc}
\hline \multicolumn{1}{c}{ Respondents } & Frequency of Response & \% of Response \\
\hline Great extent & 12 & 42.85 \\
Considerable extent & 8 & 28.57 \\
Moderate extent & 6 & 21.42 \\
Little extent & 2 & 7.14 \\
Total & $\mathbf{2 8}$ & $\mathbf{9 9 . 9 8}$ \\
\hline
\end{tabular}

Source: Survey Data 2019

Table 2 above shows that out of 28 respondents sampled, 12, which represent $42.85 \%$, said they use the techniques to a great extent for preservation and conservation of information. Eight (8), which represent $28.57 \%$, said it is to a considerable extent, while six (6), which represent $21.42 \%$, said it is to a moderate extent, and finally two (2), which represent $7.14 \%$, said it is to a little extent.

Research Question Two: Causes of deterioration of print and electronic information resources.

\begin{tabular}{lcc}
\hline \multicolumn{1}{c}{ Responses } & $\begin{array}{c}\text { Frequency of } \\
\text { Response }\end{array}$ & \% of Response \\
\hline Lack of legislation and policy & 15 & 53.57 \\
Lack of training and retraining & 9 & 32.14 \\
Poor maintenance culture & 4 & 14.28 \\
Total & $\mathbf{2 8}$ & $\mathbf{9 9 . 9 9}$ \\
\hline
\end{tabular}

Source: Survey Data 2019

Table 3 above indicates that fifteen (15) respondents, which represent 53.57\%, said lack of legislation and policy is the cause of deterioration of print and electronic information resources. Nine (9) respondents, which represent $32.14 \%$, said lack of training and retraining is the cause of EIRs. Four (4) respondents, which represent 14.28\%, said poor maintenance culture accounts for deterioration of print and EIRs.

Research Question Three: The challenges of preservation and conservation practices of print and EIRs.

\begin{tabular}{lcc}
\hline \multicolumn{1}{c}{ Respondents } & Frequency of Response & \% of Response \\
\hline Great extent & 13 & 46.42 \\
Considerable extent & 7 & 25.00 \\
Moderate extent & 5 & 17.85 \\
Little extent & 3 & 10.71 \\
Total & $\mathbf{2 8}$ & $\mathbf{9 9 . 9 8}$ \\
\hline
\end{tabular}

Source: Survey Data 2019 
Table 4 above shows that out of 28 respondents sampled, thirteen (13), which represent $46.42 \%$, said the challenges of preservation and conservation of EIRs is to a great extent. Seven (7), which represent $25 \%$, said it is to a considerable extent. Five (5), which represent $17.85 \%$, said it is to a moderate extent, while three (3) said it is to a little extent.

\section{CONCLUSION}

The study found out that the techniques adopted by Etche Local Government Council in preservation and conservation include - but are not limited to-migration, refreshing, emulation, encapsulation, etc. The causes of deterioration, techniques for preservation and challenges of presentation of old administrative records in Etche L.G.A. in Rivers State, Nigeria, have been discussed through this research work. Disasters such as fire and water were to a great extent the major causes of deterioration in old administrative record keeping. Some of the challenges facing preservation and conservation of old administrative records in Etche L.G.A. are lack of legislation policy and strategy, and lack of training and retraining, among others.

\section{REFERENCES}

Adetunale, B. O. G \& Agbetuyi, P. A. (2018). Preservation and Conservation of Electronic Information Resources in Private University Libraries of South-West, Nigeria.

Akande S.O. (2009). Knowledge, perception and attitudes of library personnel towards preservation of information resources in Nigerian Federal University Libraries. Library philosophy and Practice, 303.

Akande, S.O. 2010. Influence of knowledge and perception on personnel attitude towards preservation of Information Resources in Federal University Libraries in Nigeria. A Ph.D thesis submitted to the Faculty of Education, Department of Library, Archival and Information Studies, University of Ibadan, Ibadan, Nigeria. 18-20.

IFLA Principles for the Care and Handling of Library Materials (2010). International Preservation Issues. Number One. http://archive.ifla.org/VI/news/pchlm.pdf. 26th July, 2015

International Federation Library Association (2003). "Audiovisual and Multimedia Section Guideline for Audiovisual and Multimedia Materials in Libraries Draft June 2003".

International Records Management Trust (1999). Managing Public Sector Records: A Study Programme. Retrieved from http://www.irmt.org/documents/educ_training/public_sector_rec/IRMT_manage_archi ves.pdf 28th November, 2014.

Iyishu, V. A. et.al. 2013.' 'Preservation and Conservation of Library Materials in the Digital Age": Information Impact Journal of Information and Knowledge Management; 4.2:3645.

National Library of Australia (2004) Preservation Policy. http://www.nla.gov.au/policy/pres.html. 19th February, 2015.

National Library of Australia 2003. "Guideline for the Preservation of Digital Heritage. Netherland": Information Society Division, United Nations Educational, Scientific and Cultural Organization; 12-16 
Nwosu, O. et.al. 2013. "Challenges of Electronic Information Management in Nigerian university Libraries". IOSR Journal of Humanities and Social Sciences; 13.2:75-79.

Ogunniyi, S.O. \& Adejubee, F.V. (2014). Strategies of Curbing Deterioration of / $x$ Undergraduate projects: A Case Study of Six Selected Colleges of Education Libraries in Southern Nigeria. Library Philosophy and Practice, 1036.

Oluwaniyi, Sunday A. (2015). "Preservation of Information Resources in selected School Libraries in lbadan North Local Government Area of Oyo State, Nigeria". Library Philosophy and practice(e-journal). 1220.

Poll, R. (2007). Quality measures for special libraries. (Internet) http://www.ifla.org/IVifla73/papers/152-Poll-en.pdf. 28th August, 2015.

Popoola S. O. 2003. Preservation and Conservation of information Resources. University of Ibadan, Nigeria: Distance Learning Centre.

Popoola S.O (2003). Preservation and conservation of Information Resources. University of Ibadan, Nigeria. Distance Learning centre.

Popoola, M. O. (2006). Definition, Aims, and Objectives of Library. In Library Education Seriesed Methew O. Popoola. Akure: Moloye Education. P.I.

Sawant, S. (2014). A Study on Preservation and Conservation Practices in Academic Libraries in Mumbai. Annals of Library and Information Studies, 61(2): 153-159

Sawant, S. S.2006, Strategies for Preservation of Digital Documents: An overview: Trends in Information Management; 2.1: 23-34.

Shameenda, K.L. (2011). Preservation and Conservation of Library Materials, Techniques and, Practices: A Case Study of the University of Zambia Libraries. In: UNZA Institutional Repository (Internet)

Wamukoya, J. and Mutula, S. M. (2005). Capacity - building requirements for e-records management: the case in East and Southern Africa. Records Management Journal, 15.2: $71-79$. 